IMPROVEMENT OF FARMERS 'KNOWLEDGE ABOUT DIVERSIFICATION OF RED RAW FARMING BUSINESS RESULTS IN NAGARI KOTO GADANG GUGUAK JORONG BUKIT GOMPONG GOMPONG SOLOK KABUPATEN

\title{
PENINGKATAN PENGETAHUAN PETANI TENTANG DIVERSIFIKASI HASIL USAHA TANI BAWANG MERAH DI NAGARI KOTO GADANG GUGUAK JORONG BUKIT GOMPONG KABUPATEN SOLOK
}

\author{
${ }^{1}$ Putri Meliza Sari, ${ }^{2}$ Yolamalinda, ${ }^{3}$ Nilmadesri Rosya, ${ }^{4}$ Dola Oktavia \\ ${ }_{1,2,3,4}$ STKIP PGRI Sumatera Barat \\ Email: putrimelizasari@gmail.com, yolamalinda@gmail.com, nilmadesrirosya@gmail.com
}

\begin{abstract}
One of the activities in agriculture that contributes is horticultural farming. Solok Regency is one area that has the potential to become one of the centers of onion production because it has been the area with the largest production and planting area of shallots in West Sumatra. This activity was followed by shallot farmers in Jorong Gompong, Solok Regency who will carry out a program of diversification of shallots to fried onions. This product diversification activity can create added value, and of course it will increase the income of the farmer and to overcome the problem of overproduction which can make onions cheaper and can also cause the onions to rot, this will cause losses to the farmers. To overcome this, product diversification needs to be implemented, one of which is to make fresh shallots into fried onions.
\end{abstract}

Keywords: shallots, product diversification, income

\section{ABSTRAK}

Salah satu kegiatan di bidang pertanian yang memberikan kontribusi adalah usahatani hortikultura.Kabupaten Solok merupakan salah satu daerah yang berpotensi untuk menjadi salah satu sentra produksi bawang merah karena selama ini menjadi daerah dengan produksi dan luas tanam bawang merah terbesar di Sumatera Barat.Kegiatan ini diikuti oleh petani bawang merah di jorong Gompong Kabupaten Solok yang akan melakukan program diversifikasi produk bawang merah menjadi bawang goreng. Kegiatan deversifikasi produk ini dapat menciptakan nilai tambah, dan tentunya akan menambah pendapatan dari si petani dan untuk mengatasi masalah kelebihan produksi yang dapat menjadikan bawang merah menjadi lebih murah dan juga bisa mengakibatkan bawang menjadi busuk, hal ini akan menyebabkan kerugian kepada pihak petani. Untuk itu dalam mengatasi hal ini perlu dilaksanakan diversifikasi produk, salah satunya adalah menjadikan bawang merah segar menjadi bawang goreng.

Kata Kunci: bawang merah, diversifikasi produk, pendapatan

\section{PENDAHULUAN}

Pada negara berkembang seperti Indonesia, konstribusi sektor pertanian sangat berpengaruh untuk pembangunan negara disebabkan oleh beberapa faktor seperti: (1) sektor pertanian merupakan sumber persediaan bahan baku yang dibutuhkan oleh suatu negara, (2) kebutuhan yang meningkat akibat pendapatan meningkat, (3) adanya keharusan menyediakan bahan -bahan yang dapat mendukung sektor lain terutama industri, (4) sektor pertanian merupakan jembatan untuk menghubungkan pasar yang dapat menciptakan spread-effect 


\section{Rangkiang: لlurna/ Pengabdian Pada Masyarakat UPSM STKIP PGR/ Sumatera Barat}

ISSN: (2721-2688) Vol. 2 No. 1 (Juni 2020): 12-16

https://doi.org/10.22202/JR.2020.V1i2.3929

dalam proses pembangunan dan, (5) sektor pertanian merupakan sumber pendapatan masyarakat di negara berkembang yang hidup di pedesaan. Salah satu kegiatan di bidang pertanian yang memberikan kontribusi adalah usahatani hortikultura.Hortikultura adalah salah satu sumber pertumbuhan baru pertanian yang sangat diharapkan perannya dalam menunjang pembangunan ekonomi nasional.Komoditas hortikultura merupakan salah satu komoditas pertanian yang mempunyai potensi untuk dikembangkan, mengingat wilayah Indonesia yang sebagian besarnya cocok untuk tanaman hortikultura (Daikhwa, 2010).

Bawang Merah Solok Sumbar sangat berpotensi besar sebagai bahan campuran pokok yang menjadikan bawang produksi yang mampu memenuhi kebutuhan konsumsi masyarakat di Provinsi Sumatera Barat maupun di provinsi lainya yangada di Pulau Sumatera. Bawang Merah Solok Sumbar yang di produksi di Kecamatan Lembah Gumanti ini sudah memiliki banyak permintaan di seluruh penjuru nusantara, hal ini disebabkan oleh beberapa karakteristik, seperti rasa gurih yang khas, serta kesanggupan petani menanam bawang merah yang berkualitas tinggi dan super dengan skala yang semakin meningkat dari tahun ke tahun.

Tabel 1. Perkembangan Luas Lahan dan Produksi Bawang Merah di Kecamatan Lembah Gumanti

\begin{tabular}{ccccc}
\hline No & Tahun & Luas lahan (ha) & Produksi (ton) & Perkembangan (\%) \\
\hline 1 & 2010 & 1609 & $14.999,7$ & - \\
2 & 2011 & 2169 & $21.880,9$ & 31,48 \\
3 & 2012 & 2269 & $24.521,3$ & 10,76 \\
4 & 2013 & 2629 & $28.897,8$ & 15,15 \\
\hline
\end{tabular}

(Sumber: BPS Sumatera Barat, 2018)

Di Kabupaten Solok perkembangan pertanian bawang merah paling pesat adalah di Kecamatan Lembah Gumanti.Perkembangan pertanian bawang merah di Kecamatan Lembah Gumanti di tidak terlepas dari keadaan tanh dan cuaca yang mendukung utuk pertnian bawang merah.Petanian bawang merah di Lembah Gumanti mulai berkembang dari tahun 2010 yang terus di pertahankan petani sampai sekarang.Perkembangan produksi bawang merah di lembah gumanti meningkat dari tahun ke tahun.

Menurut Kepala Dinas Tanaman Pangan Hortikultura dan Perkebunan Provinsi Sumatera Barat, Chandra menjelaskan bahwa kawasan aneka bawang sangat prospektif di Kabupaten Solok, Agam dan Tanah Datar.Kami mendukung penuh kawasan pengembangan bawang merah di solok yang luas panennya mencapai 8.000 Ha serta potensi pengembangan bawang putih mencapai $5.000 \mathrm{Ha}$. Salah satu kendala dalam pengembangan agroindustri di Indonesia adalah kemampuan mengolah produk yang masih rendah.Hal ini ditunjukkan dengan sebagian besar komoditas pertanian yang diekspor merupakan bahan mentah dengan indeks retensi pengolahan sebesar 71-75\%.Angka tersebut menunjukkan bahwa hanya 25$29 \%$ produk pertanian Indonesia yang diekspor dalam bentuk olahan.Kondisi ini tentu saja memperkecil nilai tambah yang yang diperoleh dari ekspor produk pertanian, sehingga pengolahan lebih lanjut menjadi tuntutan bagi perkembangan agroindustri di era global ini. Teknologi yang digolongkan sebagai teknologi agroindustri produk pertanian begitu beragam dan sangat luas mencakup teknologi pascapanen dan teknologi proses.Selama ini bawang merah lebih banyak dipasarkan dalam bentuk segar. Padahal, bawang merah bisa diolah menjadi berbagai produk yang mampu memberi nilai tambah bagi para petani (Elfia, 2015).

Pengolahan produk bawang merah segar ini terutama sangat diperlukan ketika panen raya dan harga mengalami kejatuhan.Industri bawang goreng cukup potensial untuk dikembangkan, selain mampu memperpanjang daya guna bawang merah juga mampu meningkatkan pendapatan rumah tangga.Seperti umumnya industri rumah tangga, usaha ini 


\section{Rangkiang: لlurna/ Pengabdian Pada Masyarakat LPSM STKIP PER/ Sumatera Barat}

ISSN: (2721-2688) Vol. 2 No. 1 (Juni 2020): 12-16

https://doi.org/10.22202/JR.2020.V1i2.3929

juga memungkinkan penyerapan tenaga kerja khususnya tenaga kerja wanita, karena produk ini mempunyai nilai komersial yang cukup tinggi. Tujuan dari pengabdian pada petani bawang merah ini adalah mengatasi masalahdalam peningkatan pendapatan petani dengan mengolah produk bawang merah segar yang salah satunya menjadi bawang goreng di Kabupaten Solok khususnya Jorong Gompong. Jorong Gompong adalah sebuah jorong di Kabupaten Solok, Sumatera Barat. Mata pencaharian penduduk pada umumnya adalah bertani, dan sebagian kecil sebagai pedagang (wiraswasta) serta pegawai pemerintah.Industri pengolahan hasil pertanian juga dapat memberikan kesempatan kerja dan meningkatkan pendapatan petani.Menurut Kepala Dinas Pertanian Kabupaten Solok, saat ini Kabupaten Solok menjelma menjadi kawasan produksi bawang merah yang terbesar di Sumatera dengan luas panen dalam setahun kurang lebih 7.300 ha. Meningkatnya jumlah produksi bawang merah di kawasan solok ini menjadi berkah bagi petani atau pun masyarakat solok secara keseluruhan. Dengan kegiatan pengabdian ini, tim pengabdi memotivasi para petani agar meningkatkan pengetahuannya dalam mendiversifikasikan bawang merah segar menjadi bawang goreng.

\section{METODE}

Kegiatan pengabdian pada masyarakat di Jorong Gompong Kabupaten Solok mampu meningkatkan pemahaman petani bawang merah dapat melakukan diversifikasi produk terhadap hasil usahatani yang telah mereka hasilkan, sehingga melalui kegiatan ini petani dapat meningkatkan pendapatan.Kegiatan pengabdian ini dilakukandenganmenggunakan metode seperti berikut:

1. Ceramah

Materi yang diberikan adalahpenjelasan tentang cara meningkatkan pengetahuan dan memotivasi petani bawang merah agar dapat mengolah hasil usahatani bawang merah segar menjadi bawang goreng, disamping diversifikasi produk ini dapat meningkatkan pendapatan para petani, pengolahan ini juga dapat menjadi solusi pada saat panen raya, dimana produksi melimpah yang menyebabkan turunnya harga jual bawang merah segar.

2. Diskusi

Pada tiap materi yang disampaikan, peserta dapat berdialog danberdiskusi dengan tim pengabdian, dengan materi bagaimana cara meningkatkan pengetahuan petani mengenai pengolahan bawang merah segar menjadi bawang goreng dalam rangka meningkatan pendapatan petani.

\section{HASIL DAN PEMBAHASAN}

Kegiatan ini diikuti oleh petani bawang merah di jorong Gompong Kabupaten Solok yang akan melakukan program diversifikasi produk bawang merah menjadi bawang goreng. Kegiatan diversifikasi produk ini dapat menciptakan nilai tambah, dan tentunya akan menambah pendapatan dari si petani. Dalam melaksanakan kegiatan pengabdian ini para peserta mengikuti dengan antusias dan banyak sesi tanya jawab. Dengan adanya kegiatan ini diharapkan para peserta dapat memahami pentiingnya melakukan diverfisikasi produk dalam rangka peningkatan pendapatan keluarga petani. Kegiatan ini berguna untuk mengatasi masalah kelebihan produksi yang dapat menjadikan bawang merah menjadi lebih murah dan juga bisa mengakibatkan bawang menjadi busuk, hal ini akan menyebabkan kerugian kepada pihak petani. Untuk itu dalam mengatasi hal ini perlu dilaksanakan diversifikasi produk, salah satunya adalah menjadikan bawang merah segar menjadi bawang goreng. 


\section{Rangkiang: لlurna/ Pengabdian Pada Masyarakat UPSM STKIP PGR/ Sumatera Barat}

ISSN: (2721-2688) Vol. 2 No. 1 (Juni 2020): 12-16

https://doi.org/10.22202/JR.2020.V1i2.3929

Salah satu sentra produksi yang menjadi pengembangan baru dalam agribisnis bawang merah nasional adalah Kabupaten Solok di Provinsi Sumatera Barat.Kabupaten Solok merupakan salah satu daerah yang berpotensi untuk menjadi salah satu sentra produksi bawang merah karena selama ini menjadi daerah dengan produksi dan luas tanam bawang merah terbesar di Sumatera Barat.Daerah ini juga berpotensi untuk mengisi pasokan pasar di kota-kota besar di Pulau Sumatera sehingga tidak bergantung kepada pasokan dari Kabupaten Brebes.Dinas Pertanian Kabupaten Solok memfokuskan pengembangan bawang merah di empat kecamatan yang semuanya berada di dataran tinggi. Empat kecamatan tersebut adalah Lembah Gumanti, Danau Kembar, Gunung Talang, dan Lembang Jaya.Produksi bawang merah sepanjang tahun juga menjadi kekuatan di mana setiap hari terdapat panen dan tanam bawang merah. Petani bawang merah biasa menanam kembali bawang merah seketika setelah panen.Mulsa untuk budidaya bawang merah biasa digunakan tiga hingga empat kali pertanaman. Namun, di sisi lain kekuatan ini dapat menjadi kelemahan karena tidak adanya pergiliran tanaman dapat menyebabkan terjadinya ledakan hama penyakit.

Kekuatan lain yang teridentifikasi adalah sarana prasarana produksi serta pedagang antardaerah yang cukup banyak. Ketersediaan input dan saluran pemasaran tidak menjadi masalah bagi usahatani bawang merah di Kabupaten Solok. Terdapat pula pedagang antardaerah yang siap memasarkan bawang merah hasil produksi Kabupaten Solok ke pasar di kota-kota lainnya. Kekuatan lain yang dimiliki Kabupaten Solok untuk berkembang sebagai sentra bawang merah nasional adalah mandiri dalam penyediaan benih dalam hal tidak bergantung terhadap pasokan benih dari luar daerah. Selama ini petani bawang merah juga tidak tergiur dengan tingginya harga bawang merah konsumsi di beberapa waktu dan selalu menyisihkan sisa hasil panennya untuk dijadikan benih untuk musim tanam berikutnya, walaupun harga konsumsi naik.Selain itu petani juga fanatik terhadap varietas lokal yang ada di sentra produksi tersebut. Diduga varietas lokal di Kabupaten Solok masih memiliki kekerabatan dengan bawang merah di Pulau Jawa karena diketahui memiliki kelompok genotipe yang sama (Elfino,2017). Hal ini dimungkinkan merupakan pengaruh dari distribusi bawang merah di Indonesia yang mana pada masa lalu bawang merah dari sentra produksi Pulau Jawa dijual ke Sumateratermasuk Solok dapat beradaptasi dengan baik, dan disukai oleh petani. Kekuatan lain Kabupaten Solok untuk dapat berkembang sebagai sentra produksi bawang merah menurut pemangku kepentingan adalah kualitas dan produksi bawang merah yang dihasilkan baik.

\section{KESIMPULAN}

Kegiatan deversifikasi produk ini dapat menciptakan nilai tambah, dan tentunya akan menambah pendapatan dari si petani. Dalam melaksanakan kegiatan pengabdian ini para peserta mengikuti dengan antusias dan banyak sesi tanya jawab. Dengan adanya kegiatan ini diharapkan para peserta dapat memahami pentingnya melakukan diverfisikasi produk dalam rangka peningkatan pendapatan keluarga petani. Kegiatan ini berguna untuk mengatasi masalah kelebihan produksi yang dapat menjadikan bawang merah menjadi lebih murah dan juga bisa mengakibatkan bawang menjadi busuk, hal ini akan menyebabkan kerugian kepada pihak petani. Untuk itu dalam mengatasi hal ini perlu dilaksanakan diversifikasi produk, salah satunya adalah menjadikan bawang merah segar menjadi bawang goreng. 


\section{DAFTAR PUSTAKA}

Asmani, Jamal Ma`mur. 2011. Buku Panduan InternalisasiPendidikan karakter di Sekolah. Yogyakarta: Diva Press.

Dahliyana, Asep. 2017. "Penguatan Pendidikan KarakterMelalui Kegiatan Ekstrakurikuler Di Sekolah.”Jurnal SosioreligiVolume 15 Nomor 1 Tahun 2017.

Karen E. Bohlin, Deborah Farmer, Kevin Ryan.2001. Building Character in School ResourceGuide. San Fransisco: Jossey Bass.

Novia Wahyu Wardhani, Nugraheni Arumsari, Tutik Wijayanti. 2019. "Pemahaman Pentingnya Kesadaran Akan Pendidikan Karakter Anakmelalui Sinergi Lingkungan Pendidikan di Kecamatan Gunungpati”. JurnalPanjar,Volume 1 Nomor 2 Tahun 2019, hal. 107-110.

Undang-Undang No. 23 Tahun 2002 tentang Sistem Pendidikan Nasional 